https://dx.doi.org/10.4314/iijikm.v10i1.2

Information Impact:

Journal of Information and Knowledge Management

Vol. 10 (1), June, 2019

ISSN: 2141-4297 (Print) ISSN: 2360-994X (Online)

\title{
Digitization of Library Materials in Special Libraries in Abuja, Nigeria
}

\author{
${ }^{1}$ Rose Lade Mommoh \& ${ }^{2}$ Saka Katamba Abubakar \\ ${ }^{1}$ University of Abuja, Nigeria \\ ${ }^{2}$ Federal University of Technology Minna, Nigeria
}

\begin{abstract}
The Survey method was utilized in the conduct of this research. The population for the study consists of fifty three (53) special libraries in Abuja, the Federal Capital Territory. The sampled population for the study comprised of fifty six (56) librarians (two (2) librarians each), from twenty eight special libraries which were randomly selected. Structured questionnaire was used for the collection of data for the study. Descriptive statistics, mean score and standard deviation was used for the analysis of data. Findings from the study revealed that ICT resources available in special libraries in the Federal Capital Territory, Abuja are grossly inadequate. However attitude of librarians in special libraries to digitization of library materials was found to be positive. The study also revealed inadequate funding for digitization of library materials in the special libraries studied. Based on the findings some recommendations were made.
\end{abstract}

Keywords: Digitization, library materials, special libraries, Abuja,

\section{Introduction}

Special libraries are established along a specialized field. They could be found in Government Departments, public authorities, research institutes, business organizations, industrial firms, medical and pharmaceuticals corporations etc. Special libraries often cover a specific and definable subject field. The printed collection of a special library is mainly in the areas of periodicals, books, reports (consultancy report, technical reports and feasibility studies), executive summaries and abstracts. The needs of the user are highly specific.
In the $21^{\text {st }}$ century, special libraries in Nigeria have integrated technology in their operations. This serves as a mechanism for improvement and development especially where attention is drawn to academic contents and ways of preserving information resources for future use. Special libraries have long played the role of collecting, preserving and sharing information.

The traditional methods of preserving paperbased materials seem not to be adequate enough and hence a more recent method of preserving paper-based materials known as 
digitalization is used. Digitization is fast becoming popular and essential in the sustenance of information services delivery in libraries and information centers. Alegbeleye (2007) defined digitization as the conversion of an analogue signal or code in to a digital signal or code. According to Fatoki (2005) digitization is the conversion of analogue media form. Ogundana (2007) defined digitization as "the process of translating a piece of information such as sound recording, picture or video into bits and this process can be accompanied through a variety of existing technologies". Igbeka (2008) defined digitalization as a process towards building digital libraries, which involves taking traditional library materials typically in form of books and papers and converting them to electronic form where they can be stored and manipulated by a computer. Okwaro (2010) taking a functional look at the process defined the act of scanning an analog document into digital copy being made available to end users via the internet or other means for a sustained length of time. The aim of digitization is to contribute the local content to the global information network (GIV), increased access and long term preservation of information materials in order to avoid the deteriorations often associated with paper collection. Archimedia (2005) identified a number of reasons for digitization which include reduction or elimination of the volume of necessary operational space for its storage, reduction of the maintenance cost for the printed materials, faster search and access to the required information through a terminal access possibility to the same information for more than one user simultaneously through a terminal, possibility for graded access and maximization of data security. Fubunmi (2006) also identified three major reasons for digitization endeavor which include: The need to preserve endangered library resources, improvement of the efficiency of information search mechanism, and improving access to library resources. According to Agbo (2015), digitization has offered a new preservation paradigm and also the opportunity of preserving the original by providing access to the digital surrogate. It is increasingly impacting on the preservation of our cultural heritage and global accessibility of our local content. On this Ezeani and Ezema (2009) posit that digitation encourages globalization of local information content and localization of global information resources. Digitization has equally alleviated the problem of poor storage environment normally associated with the manual preservation of information materials especially in developing countries. Digitization therefore, offer the opportunity of global access to digital information, ensures the preservation of rare, fragile and cultural heritage materials, alleviate space constraint, encourage collaboration, knowledge creation and interoperability.

Igbeka (2008) asserts that digitization of library materials can play an outstanding role in the enhancement of information development in Nigeria and African as a whole and that accessibility, retrieval, storage and preservation of information can be less cumbersome when the process of digitization is utilized. Arguing for digitization in government libraries, Fanimehin (2008) stated that in government 
libraries, materials should be tailored to the objectives of the government. However there are library materials that are often common in government libraries. These include official gazette, periodicals, financial regulations, federal staff list, official circulars, and law reports, Acts of parliament, annual budget and reports etc. That it is the duty of the librarians to ensure the preservation of these materials for easy access, retrieval and prompt delivery to users of these materials. This would be done better with digitalization. To Fanimehin (2008) digitalization would enhance the preservation of materials in government libraries.

According to Johnson (2008) digitalization brings better preservation of library materials and makes information readily available to users and also improves

\section{Objectives of the Study}

The specific objectives of this study are to:

(1) Determine the availability of ICT in the special libraries understudy.

(2) Investigate the types of library materials that have been digitized in the special libraries under study.

\section{Literature Review}

Fotoki (2007) considering the overview of digitization programme in Nigerian institutions revealed that research have shown that out of fourteen (14) Federal university libraries surveyed, only five (5) institutions have digitized programme. The type of resources digitized by Federal university libraries includes: abstract of resource sharing materials. Adebayo (2010) asserts that digitization enhance the reputation and visibility of an organization, show casing the intellectual quality of the institution. Also Igbeka and Ola (2009) stressed that digitization demands less physical storage of materials and reduction in handling and use of fragile and heavily used original materials. According to Ndor (2006) cognizant of the opportunities provided by developments in information dissemination and exchange, some libraries in Nigeria have made efforts to digitize their collections to make it available into the main stream of the world knowledge". This study seek to investigate the extent of digitization of library resources in special libraries in Abuja the Federal Capital Territory.

3. Find out the attitudes of librarians towards digitization in special libraries in Abuja, .

4. Determine the extent of problems associated with digitization of library resources in the special libraries under study.

theses, newspapers, manuscripts and African collection. Other eight state university libraries were also surveyed and out of the four (4) studied, only one (1) digitized newspaper and past question papers. National library indicated to have digitization programme which is digitization of newspapers. National archives were not left out in the study and only national 
archive surveyed do not have neither digitization programme nor the type of resources being digitized. The above situation is that of university libraries, national library and national archive in Nigeria. The state of digitization of library materials in special libraries is not known. Therefore these studies investigate the level of digitization in special libraries considering the advantages provided by technology.

Ilesanmi (2013) investigated the processes of journal collection digitization in Kenneth Dike Library, University of Ibadan. Underfunding and copyright clearance are the challenges encountered among others. The study recommends adequate funding and concludes that the benefit of instant access to digital information is the most distinguishing attribute in this present information age. Eke (2011) also gave an overview of digitization and the digitization initiatives in the University of Nigeria

\section{Methodology}

Survey method was utilized in the conduct of this research. The population for the study consists of fifty three (53) special libraries in Abuja, the Federal Capital Territory. The sampled population for the study comprised of twenty eight special libraries which were randomly selected as sample for the study.
Nsukka including the processes, A number of challenge facing successful digitization of resources in University of Nigeria, Nsukka. Major deterrents in the project include legal aspect and finances.

Report from National Diet Library of Japan on library material digitization (2018) revealed that the library has been converting the content of their materials into other media to achieve compatibility of use and preservation. A micro filming programme was originally used as a method for preserving valuable materials. But since 2009, the National Diet Library (NDL) has been digitizing them for preservation of materials and for digital library service. It also listed the materials that have been digitized to include books, periodicals, rare books and old materials, doctoral dissertations, official gazettes, modern Japanese political history materials and audio-visual materials and others.

From each library selected, two (2) librarians were randomly selected making a total of fifty six (56) librarians as sample for the study. Structured questionnaire were used for collection of data for the study. Frequency counts, percentages and mean score were used to analyze the data collected from the respondents. 


\section{Presentation of Results}

The results of the analysis are presented in the tables below:

Out of fifty six (56) questionnaire administered, fifty (50) were completed and returned.

Research Question 1: What type of ICT resources is available in your library?

Table 1: Available ICT resources in special libraries in Abuja-Federal Capital Territory

$\begin{array}{lcc}\text { ICT's Facilities } & \text { Available } & \text { Not available } \\ \text { Computers } & 32(64 \%) & 18(36 \%) \\ \text { Internet } & 18(36 \%) & 32(32 \%) \\ \text { Scanners } & 10(20 \%) & 34(40 \%) \\ \text { Intranet } & 18(36 \%) & 32(32 \%) \\ \text { Library website } & 13(26 \%) & 37(74 \%) \\ \text { Library application } & 28(56 \%) & 22(44 \%) \\ \text { software } & & \\ \text { OPAC } & 7(14 \%) & 43(86 \%) \\ \text { Wireless Network } & 15(30 \%) & 35(70 \%)\end{array}$

Table 1 showed the available ICT resources in special libraries in Abuja, Federal Capital Territory. Data revealed that $32(64 \%)$ and $28(56 \%)$ librarians respectively agreed that computers and library application software were available and above average in special libraries in Abuja, Federal Capital Territory. Other ICT resources available includes internet 18(36\%), scanners 10(20\%), intranet $18(36 \%)$, library website $13(26 \%)$, OPAC $7(14 \%)$ and wireless network
15(30\%). The available ICT in special libraries in Abuja, Federal Capital Territory are still very low since majority of ICT resources are below average. The low level available ICT resources can negatively affect digitization programme in the special libraries in Abuja, Federal Capital Territory since some ICT resources on table one (i) are fundamental requirements for digitization

\section{Research Question 2:}

Are the following the library materials digitized in your library?

Table 2: Library materials digitized in the special Libraries.

Types of Digitized library materials in Yes No special Libraries in Abuja

Thesis/dissertation $\quad$ - $50(100 \%)$

Newspapers/Magazines $\quad$ - $50(100 \%)$

Seminar/Conference/Workshop Papers $\quad$ - $\quad 50(100 \%)$

Technical reports and patents $\quad$ - $\quad 50(100 \%)$ 
News letters

Journal articles

Ceremonial addresses

Manuscripts

Circulars

Annual budget and reports

Directories

Official gazette

Law reports

Other organization publication

On the type of digitized library materials in special libraries Abuja, Federal Capital Territory. 6(12\%) librarians agreed that they have digitized journal articles while $8(16 \%)$ have also digitized circulars. Journal articles and circulars digitized are very low. All the librarian in the research study in special libraries Abuja, Federal Capital Territory agreed that library materials such as Thesis/dissertation, Newspapers/Magazines, Seminar/Conference/workshop papers, Technical reports and patents, Newsletters, Ceremonial address, Manuscripts, Annual

$\begin{array}{cl}- & 50(100 \%) \\ 6(12 \%) & 44(88 \%) \\ - & 50(100 \%) \\ - & 50(100 \%) \\ 8(16 \%) & 42(84 \%) \\ - & 50(100 \%) \\ - & 50(100 \%) \\ - & 50(100 \%) \\ - & 50(100 \%) \\ - & 50(100 \%)\end{array}$

budgets and reports, Directories, Official Gazette, Law reports and other organizational publications have not been digitized.

From the above analysis, one can infer that the level of digitization in special libraries in Abuja, Federal Capital Territory is very low and can deduce that digitization of information resources in special libraries in Abuja, Federal Capital Territory have not actually commenced.

\section{Research Question 3}

What is the attitude of librarians to Digitization in special libraries in Abuja FCT?

Table 3: Attitude of librarians to digitization in special libraries in Abuja FCT.

item

The digitization process is fast and good.

The librarians are not proactive to digitization

I don't like digitization

There is fear of copyright violation

Digitization process is easy.

$\begin{array}{lll}\begin{array}{l}\text { MEAN } \\ (\mathbf{X})\end{array} & \text { SD } & \text { Rema } \\ 3.0 & .02300 & \mathrm{~A} \\ 2.6 & .54772 & \mathrm{SD} \\ 1.6 & .09443 & \mathrm{D} \\ 3.8 & .44721 & \mathrm{~A} \\ 2.6 & .54772 & \mathrm{SD}\end{array}$

agreement that digitization process was fast and good. While mean score of (2.6) librarians indicates that librarians were not
On the attitude of librarians to digitization in special libraries, Table 3 revealed the mean score of (3.0) indicating librarians 
proactive to digitization. Only (1.6) disagreed that librarians don't like digitization, which means that majority of the librarians like digitization. (3.8) librarians agree that there is fear of copyright, violation and (2.6) disagree that digitization process is easy. From the above analysis, one can conclude that librarians have positive attitude towards digitization of library resources.

\section{Research Question 4.}

What is the extent of problems associated with digitization of library materials in special libraries in Abuja?

\section{Table 4: Digitization of library materials in special libraries in Abuja}

\section{ITEM}

There is no clear cut policy on information preservation in your library

There is no adequate fund for digitization project in my library

There is no adequate fund for digitization in the library

My parent organization does not support digitization in my library

There is no training programmes for updating the staff skills for digitization

There are no skilled staff for digitization

There is no adequate power supply to enhance digitization in my library

There is adequate motivation of library staff

There are no relevant hardware, software and constant internet connectivity in your library for digitization

MEAN

(X)

3.0

4.7

3.6

2.6

3.4

3.2

4.3

3.2
SD

.00000

.50000

.72648

.52705

.52705

.44096

.70711

.70711 SD

.44096
Remark

A

SA

A

SD

A

A

SA

A

Note: accepted Mean $=2.55$ and above, Not accepted Mean $=2.55$ below. $($ Benchmark $)$

Several problems were associated with digitization of library materials in special libraries in Abuja, Federal Capital Territory. As revealed in table 4, from the mean scores, the major problems includes, clear cut policy on preservation of collection in library, (3.0), there were no adequate fund for digitization project in my library (4.6), my parent organization does not support digitization in the library (3.5), there is no fund for training library staff to update their skills for digitization (3.2), there is no adequate power supply to enhance digitization in my library (4.3) and there is no relevant hardware, soft and internet connectivity in my library for digitization (3.2). 


\section{Discussion}

The study has revealed low available ICT resources in special libraries in Abuja the Federal capital Territory. This agrees with Mommoh (2006), who found low level of availability of ICT resources from their studies. The low available ICT resources can negatively affect digitization programmes in special libraries in Abuja, Federal capital Territory, since some ICT resources on table one (1) above are fundamental requirement for digitization. The study has also revealed low digitization of library resources in

\section{Conclusion}

We live in digital age and the whole world is going digital. This therefore place a demand on special libraries to key into digitization to ensure proper preservation of their materials, making their collection more visible, make their collection available into the main stream of world knowledge. With several problems associated with digitization in special libraries, it will be very difficult for them to properly key into digitization. it is therefore necessary that the parent organization be persuaded to increase special libraries fund. This will enable the special libraries to acquire, relevant and adequate technologies required for special libraries in Abuja, Federal capital Territory. This finding agrees with Fatoki (2007) who found low level of digitization of library materials in Federal and State Universities libraries in Nigeria as well as National Library and National archives in Nigeria. The implication of this finding is that the information resources in special libraries in Abuja Federal Capital Territory have not been made available into the main stream of world knowledge, therefore the resources of special libraries in Abuja cannot be known and accessed by others outside the libraries.

digitization and to also train and prepare the library staff for digitization. The special libraries should make effort to seek for fund from donor agencies within and outside Nigeria,

The parent organization and the government of Nigeria should have a clear cut policy on preservation of information resources in libraries to encourage library staff to key into digitization. If the government policy makes it mandatory for all libraries to preserve their information resources by digitizing them and also support it by adequate provision of fund, the special libraries will have no choice but to adhere to the policy. 


\section{References}

Adebayo, E. L (2010). An institutional repository (IR) with local content at the

Redeemer's university; benefits and challenges. In Walker, C.M and Agbo, A. D (2015). Digitization of library resources in Nigeria: Problems andProspects.

International journal of information research and Review 2 (1) 256 - 260. Jan.

Alegbeleye, G. O (2007). Strategic and management issues in the digitalization ofLibrary materials. AGOL Ibadan, 2007.

Archimedia, S. A (2005). The digital library software and digital service, Athens Retrieved from: http://www.ynet.gr/archimedia on 16th Nov. 2018.

Eke, H. N (2011). Digitizing resources for University of Nigeria repository: processAnd challenges: 8 (1), $1-19$.

Ezeani, C. N. and Ezema, I. J (2009). Digital preservation of the cultural heritage of University of Nigeria Nsukka; issues and current status: in: Libraries creates Future; Building on cultural heritage. Paper presented at the $47^{\text {th }}$ National Conference and annual general meeting of the Nigerian library Association 2009 Ibadan: HEBN publishers.

Fabunmi, B. A (2006). Digitization of library resources; Challenges and implication For policy and planning: International journal of African and American Studies.

Fanimehin, A. O (2008). Planning for digitization of library materials. A paperPresented at the $6^{\text {th }}$ animal seminar/workshop on "globalization ofInformation: Trends and processes in Government libraries and Information centres" held at the Kano state, library board Kano from $23^{\text {rd }}-29^{\text {th }}$ Nov. 2008.

Fatoki, O. C (2005). The digitization handbook for information professionals,Ibadan. Hanser's publication.

Fatoki, O. C (2007). Digitalization of library materials in Nigeria; issues andConsideration for information professionals. African journal of library,Archival and information science 7(1), 17-21.

Feather, John and Paul Sturges (1997). International encyclopedia of informationScience, London. Routledge.

Igbeka, J. U (2008). Entrepreneurship in library and information services. Lagos:Striling - Hording Publishers Ltd. Pp. 93.

Igbeka, J. U and Ola, C. O (2009). The need for digitization of special materials inNigerian University Libraries: Retrieve on Dec. $28^{\text {th }} \quad 2011$ fromhttp://www.worlib.org./vol. 18 n0 1/igbekai - visni/shtm/.

Ilesani, T. C (2013). Digitization of journal collections in libraries. A case study ofKenneth Dike library, University of Ibadan, Nigeria. Journal of interlibraryLoan, Document Delivery and Electronic Reserve, Vol. 23 Pp. 35 - 45. National Diet Library, Japan (2018). Digitization of library materials.www.ndl.go.jp $>$ preservationsdigiti zation.

Ndor, J (2006). Digitization in Libraries: a practical experience paper presented inAbuja Infolib Journal of library and information science Vol. 3. No. 1 Dec, Pp. $24-35$. 
Ogundana, L. B (2007). Critical materials in the digitization of GovernmentLibraries. AGOL Ibadan, 2007.

Okwaro, D. P (2010). Digitization of libraries/archives and development. Inc. M,Walker, and M. Pickover (eds) proceeding of the first internationalConferences on African digital libraries and archives (ICADLA) 1-3 July 2009. Addis Ababa: United Nations Conferences Centre.

Usman I. A (2007). Digitization of library resources: a practical approach. PaperPresented at the national workshop on digitization of library materials:Processes and tools at computer centre. University of Jos, July $16^{\text {th }} 2007$. 